\title{
COST ACCOUNTING IN EARLY REGULATED MARKETS: \\ THE CASE OF THE ROYAL SOAP FACTORY OF SEVILLE (1525-1692)*
}

IE Working Paper $\quad$ WP $16 / 03 \quad 2710$ / 2003

\author{
Salvador Carmona \\ Instituto de Empresa \\ Department of Control \\ María de Molina 12, $5^{\circ}$ \\ 28006 - Madrid \\ Spain \\ salvador.carmona@ie.edu
}

\author{
Rafael Donoso \\ University of Seville \\ Department of Accounting and Finance \\ Avenida Ramón y Cajal, 1 \\ 41071 - Seville \\ Spain \\ rdonoso@us.es
}

\begin{abstract}
Regulated markets and state-owned monopolies characterized the economies of many Southern European territories around the end of the Middle Ages and during the Renaissance. Although this economic form was of considerable importance in implementing public policy at the time, investigation into the functioning of cost accounting in such contexts has been consistently neglected in accounting research. In this paper, we examine the role of cost systems in early regulated markets by focusing on the case of the soap production and distribution monopoly in the City of Seville, Spain. In 1423, the King of Castille granted the soap monopoly to the Duke of Alcalá as a reward for his war achievements, but pricing decisions rested in the hands of the local government. Disputes between the Duke of Alc ala and the local government (the parties) about the fair price of a pound of soap were negotiated after the development of tests that replicated the soap production process and determined its cost through complex calculations.
\end{abstract}

\section{Keywords}

Institutional Sociology, Regulated Markets, Early Cost Accounting, Spain

\footnotetext{
* Earlier versions of this paper were presented at the Research Conference of the Academy of Accounting Historians (Santa Fe, USA), the Raymond Konopka's Memorial Workshop (Seville, Spain), the Congress of the European Accounting Association (Venice, Italy), the $3^{\text {rd }}$ Euro-Conference on Management Accounting Change (Siena, Italy) and the Research Seminar Series of the University of New South Wales (Sydney, Australia). We are grateful to the participants in these events for their many helpful suggestions on earlier drafts of this paper as well as to Marcia Annisette, Wai Fong Chua, Mahmoud Ezzamel, Richard K. Fleischman, Anders Grönlund, Sten Jönsson, Habib Mahama, Gary J. Previts and the three anonymous referees of this journal.
} 



\section{INTRODUCTION}

Research on $18^{\text {th }}$ and $19^{\text {th }}$ century organizations has enhanced extant knowledge about the role of early cost systems in the public sector and of firms operating under monopolistic conditions (Hoskin and Macve, 1986, 1988; Carmona, Ezzamel and Gutiérrez, 2002). However, the limited intersection between the time span and the focal settings of these investigations has restricted the diversity of issues under investigation and constrained research advancements in this area (Meyer, 1986). Paraphrasing Scott (1995: 146), it would be difficult, if not impossible, to discern the causes and consequences of the implementation of early cost accounting systems if all our cases were embedded in the same or similar contexts. Therefore, different strands of historical research in management accounting concur that we still have much to learn about the extent to which early cost systems met the demands of organizational objectives in varying circumstances (the Economics-Based School: Boyns and Edwards, 1997b; the Foucaldian School: Hoskin and Macve, 2000). In particular, we argue that an examination of the ways in which cost calculations mediated the enforcement of monopolies and regulated markets in many Southern European territories during the Middle Ages and the Renaissance could augment our understanding of the role of such systems in mature, $19^{\text {th }}$ and $20^{\text {th }}$ century public sector organizations (Covaleski and Dirsmith, 1995; Carmona and Macías, 2001) and the interrelationship between accounting and the state during the Renaissance (Miller, 1990).

Archival evidence supporting this investigation is gathered from the Royal Soap Factory of Seville (Reales Almonas de Sevilla - RAS) ${ }^{1}$, which from 1423 to $1811^{2}$ enjoyed the royal privilege of being the sole producer and purveyor of soap to the City of Seville, Spain. The royal decree that granted this monopoly also established that the price of soap should be set by the local government of Seville. In these circumstances, the RAS and the local government (hereafter called "the parties") became enmeshed in disagreements about the fair price of soap. These disputes were negotiated around ad-hoc tests that replicated the production process of soap and aimed at tracking its manufacturing and administrative costs through complex calculations. Our investigation draws on primary evidence about the tests that were conducted in the $16^{\text {th }}$ and $17^{\text {th }}$ centuries and on extensive correspondence among the RAS, the local government of Seville, and the Royal House.

This article may be of interest to readers for at least two reasons: 1) its treatment of a neglected issue in the history of accounting and 2) its institutional sociological perspective, which places cost accounting at the interface of business organizations and the state.

\footnotetext{
${ }^{1}$ Archival evidence comes from the Archivo Ducal de Medinaceli, Seccción de Alcalá (Archive of the Dukedom of Medinaceli, Alcalá Section - ADMSA) and the Archivo Municipal de Sevilla (The Municipal Archive of Seville - AMS). We have also gathered primary data on some aspects of the wider contexts of our investigation from the Archivo General de Indias (The General Archive of Indies - AGI). The archives are well preserved and free access is provided to researchers. Fortunately, ADMSA and AMS are specialized archives that contain records of the perspectives of the RAS and the local government of Seville, thereby enabling us to cross-check the consistency and reliability of our data sources. The archives do not contain information on the overall financial accounting system of the RAS, and it is therefore impossible to determine the firm's profits during our observation period.

2 The soap monopoly lasted until August 6, 1811, when the Spanish Parliament abolished private monopolies.
} 
First, we approach the environmental circumstances that witnessed the functioning of cost accounting in a setting (i.e., early regulated markets in Southern Europe) and a time (i.e., the $16^{\text {th }}$ to $17^{\text {th }}$ centuries) that has been consistently neglected by accounting historians. By doing so, we expect to enhance understanding about the technical and discursive natures of cost calculations and their role in enforcing public policy at the outset of regulated markets. In particular, we aim at elucidating the role of cost accounting in a monopoly that was originally granted, not to signal recognition for efficient management, but to express royal gratitude for war achievements.

Second, we draw on the contributions of institutional sociology to render visible the functioning of cost accounting in the interface of business organizations and the state, an area that is considered to be promising within this stream of research (Meyer, 1986: 355). In the case of the monopoly on the production and distribution of soap, cost calculations became one of the bases for negotiating the price of this public good and a platform for the parties' active attempts at manipulating the price of soap in their favor. Through this investigation we focus explicit attention to a neglected area in institutional theory: the role of human and organizational agency in the establishment and development of societal norms (DiMaggio, 1988; Dacin, Goodstein and Scott, 2002). As noted by Carruthers (1995: 324), organizations frequently play an active role in the construction of norms and beliefs or in the shaping of their application in particular instances. In this study, we focus on the contrast between behavior and intention: the behavior of the parties, which apparently accepted the test as a basis for resolving their disputes on the price of soap; and their intention of shaping, for their own benefit, the particulars of the tests and their concomitant cost calculations.

The remainder of this paper is organized as follows. The next section addresses concepts in the new institutional sociology that are useful in explaining our findings. We then examine the wider political and social contexts that witnessed the events under investigation and present the historical background of the soap business in the City of Seville. The next two sections describe the specifics of the tests, particularly by focusing on cost calculations and their role in price setting. Two of the tests that were carried out during our observation period (1525-1692) are examined in detail. We first address the 1525 test, which depicts a case of materials that were newly purchased specifically for the test; and continue with a description of the tests conducted in 1615 that illustrate a case in which the parties used newly purchased materials as well as those taken from the RAS warehouse inventory. In the following section, we examine the role of tests and cost calculations in price setting during the period 1640-1692. Findings are discussed in the final section, which establishes the limitations of this study and suggests further research in the area.

\section{INSTITUTIONS, ORGANIZATIONS, AND LEGITIMACY}

A central tenet of institutional sociology is that organizational contexts are "characterized by the elaboration of rules and requirements to which individual organizations must conform if they are to receive support and legitimacy" (Scott and Meyer, 1983: 149). Rules and requirements to which organizations should conform are known as institutions. Organizations that conform to institutions avoid external claims of irrationality and negligible behavior. For example, there are pressures on modern organizations to increase quality across their value chain. In response to these demands, 
firms create quality departments to plan and execute quality management and because $\mathfrak{i}$ is particularly important to convey the appearance of a quality commitment to external parties such as customers, accreditation agencies, and the public at large. As noted by institutional sociologists, "being technically efficient is not the only path to organizational survival. Achieving legitimacy in the eyes of the world, state, powerful professions, or society at large, is another effective survival strategy" (Carruthers, 1995: 317). Legitimacy is defined as "the generalized perception or assumption that the actions of an entity are desirable, proper, or appropriate within some socially constructed system of norms, values, beliefs, and definitions" (Suchman, 1995: 574). Deephouse (1996: 1025) identifies two types of legitimacy: regulatory endorsement, the acceptance of an organization by the state agencies that formally regulate it; and public endorsement, the acceptance of an organization by the general public.

Firms deploy active agency in their pursuit of legitimacy (Meyer and Rowan, 1977; Scott, 1987). As noted by DiMaggio (1988: 15), "recruiting or creating an environment that can enact their claims is the central task that institutionalized entrepreneurs face in carrying out a successful institutionalization project." Thus, interested parties lobby before the legislature to influence the content of bills, and within firms, managers, can exert active agency to the extent of their latitude in manipulating their external environment (Oliver, 1991). The organizational deployment of legitimacy-building strategies involves "(a) efforts to conform to the dictates of preexisting audiences within the organization's current environment, (b) efforts to select among multiple environments in pursuit of an audience that will support current practices, and (c) efforts to manipulate environmental structure by creating new audiences and new legitimating beliefs" (Suchman, 1995: 587,). A common characteristic of these strategies is the striving of institutional entrepreneurs to make a case for the technical nature of rules and norms (Scott and Meyer, 1991: 124) in an attempt to maintain an appearance of rationality (Carruthers, 1995: 315). In this respect, institutional theorists depict cost accounting calculations like technical tools that are seen to engender legitimacy (Dirsmith, 1986: 358; also Meyer, 1986).

\section{THE CONTEXTS}

\section{The country}

During the $16^{\text {th }}$ and $17^{\text {th }}$ centuries - our period of observation - the House of Habsburg reigned in Spain and over a vast number of territories in Europe, Latin America, and Asia. The Spanish empire's mode of governance during the $16^{\text {th }}$ and $17^{\text {th }}$ centuries was greatly influenced by the imprint of King Philip II (1527-1598), who reigned from 1556 to 1598 (Lynch, 1997). Philip II conceived of the state as a centralist and bureaucratic organization in which decisions were made at the top of the hierarchy - by the King or his Royal Council - after examination of documentary support. Therefore, Philip II preferred to write and read rather than discuss; as he once said in a royal hearing, "Don Alonso, talk to me in writing" (Kamen, 1997: 235). This penchant for written documents made him known the "king of paperwork" (Kamen, 1997: 225), an attitude that slowed the decision-making process within the Spanish state at a time when its expansion and growth required flexibility and dynamism (Vázquez de Prada, 1990: 41). As he stated in his deeds, Philip II believed himself to be entrusted with absolute power (Kamen, 1997: 225), a conviction that led him to believe that he was accountable only to God. This 
perspective, along his idiosyncratic sense of justice, resulted in "guile and bloody despotism" (Lynch, 1997: 25).

Philip II was an extremely pious person. In a letter written in 1566 to his ambassador in Rome, he said: "You may assure His Holiness that rather than suffer the least damage to religion and the service of God, I would lose all my states and an hundred lives, if I had them; for I do not propose nor desire to be the ruler of heretics" (Encyclopaedia Britannica, 1994). Accordingly, Philip II made every effort to support the pervasion of the Catholic Church over the civil and political spheres of life. To ensure that his goal was achieved, he reinforced the supervisory gaze and scope of control of the Inquisition (Lynch, 1997). For the purposes of this paper and our examination of the role of cost accounting systems in regulated markets, it is interesting to note that Philip II incorporated into his vision of the economy the dictates of the Schoolmen: "those who govern the state must determine the just measure of things saleable ... it is not lawful to disregard such measures as are established by public authority or custom" (St. Thomas Aquinas, 1273: 320). In accordance with this doctrine, the Habsburgs endorsed the policy of the Castillian kings during the Medieval Ages by deploying regulated markets to ensure the "just price" of goods (de Roover, 1967). Typically, public authorities set a price that was supposed to be equal to or slightly higher than the average cost of materials, for in Catholic Renaissance Spain the ideal of public service predominated over any ideals about private profit (Carmona and Donoso, 1999). Thus, the public policy of early regulated markets in Spain relied on considerations of what present-day terminology would label "rate-of-return regulation" (Laffont and Tirole, 1993: 13-19).

\section{The City}

On January 20, 1503, the Catholic kings granted the monopoly of Spanish trade with Latin America to the City of Seville through the enactment of the Casa de la Contratación de Indias (House of Trade; see AGI. Sección Patronato. Legajo 25. Ramo 1), a state-owned agency that acted as a board of trade, a commercial court, and a clearing house for American traffic and that masterminded and centralized the commerce of the metropolis with its overseas colonies (Piernas Hurtado, 1907; Donoso Anes, 1996). As consequence of this privilege, the city witnessed the inflow of exotic spices and precious metals from Latin America, making Seville a prosperous city, the commercial capital of Spain, and an extremely expensive place to live (Caballero Bonald, 1991). Morales Padrón (1977: 201) found, for example, that inflation in Seville increased by $107 \%$ between 1503 and 1550, a trend that continued for at least the next 50 years. The extent to which price increases may be solely attributed to the inflow of precious metals from Latin America is still a contentious issue in economic history, as some commentators argue that Seville's high inflation may have been partly ascribed to the state's high debt, the decrease in agricultural production during this period, and the lack of industrial infrastructure (Hamilton, 1975; Domínguez Ortíz, 1984).

During the $16^{\text {th }}$ and $17^{\text {th }}$ centuries, Seville was a city of contrasts. Its wealth attracted intellectuals, artists, and novelists who sought to make a living from the fortunes of private philanthropists, publishers, and the Catholic Church. Miguel de Cervantes, the author of El Quixote, made many long visits to Seville in the 1560 s and lived there between 1585 and 1601. Painters like Murillo, Valdés Leal, and Velázquez; writers like Mateo Alemán; and sculptors like Martínez Montañés, all of whom were born in Seville, 
found in the city the sort of supportive environment that allowed them to develop their talents and to build a reputation that has lasted for centuries (Caballero Bonald, 1991). At the same time, Seville experienced steady demographic growth, as shown by a population increase from 55,000 inhabitants in 1533 to 121,505 in 1597 (Morales Padrón, 1975: 65). Unfortunately, this demographic explosion also resulted in huge pockets of poverty, and many people lived under miserable conditions (Morales Padrón, 1975; Domínguez Ortiz, 1984). Entire neighborhoods were infested with bad odors and dirt, which fostered outbreaks of disease in 1565-1568, 1580, 1599-1601, and particularly during 1648-1649 when the devastating Black Plague claimed a third of the population of Seville, including Martínez Montañés (Caballero Bonald, 1991; Encyclopaedia Britannica, 1994). The consumption of soap during this period could not be attributed to a personal taste for bathing, for soap was both a luxury and a poorly regarded social practice. As Philip II stated, personal bathing was a "not too Christian activity but a vicious tradition of Jews and Moorish" (Caballero Bonald, 1991: 47). However, the physicians of the day recommended soap to fight disease. As one said: "there is no better medicine (to tackle contagia) than a good laundry of the body" (ADMSA. Legajo 53-2). In 1525, when the population of Seville was 55,000, expected production of soap was 417,000 lbs (ADMSA. Legajo 51-4; AMS. Section 1, Litigios, Folder 116, Number 57) - an annual consumption of 7.6 pounds/person.

\section{THE SETTING}

In the Middle Ages, the City of Seville enjoyed the reputation of a high-quality soap producer (González Moreno, 1975) for two reasons: the sophisticated process of soap production, as introduced by the Arabs during their occupation of the city between the $8^{\text {th }}$ and the $13^{\text {th }}$ centuries $^{3}$; and the quality of raw materials utilized, especially the olive oil and ashes produced in the Guadalquivir Valley. It was customary for the kings of Castille to grant territories or monopolies over economic activities to members of the knighthood and the Catholic clergy who excelled in their services to the Crown through such activities as helping the Kingdom to reclaim Andalusia from the Arabs during the Middle Ages. Following this tradition, King Enrique II issued a royal decree on May 23, 1396, to grant the monopoly of soap production and distribution in the City of Seville to Archbishop Ruy López-Dávalos (ADMSA. Legajo 55-16). Until 1423, this royal privilege was extended or transferred to other individuals. At that time, King Juan II expanded the privilege from the City of Seville to its entire area of influence and granted it to Admiral Alonso Enríquez, who simultaneously received the Dukedom of Alcalá (ADMSA. Legajos 55-17 and 57-7). In this manner, the King expressed gratitude to the Duke for his war achievements, and the monopoly over soap production and distribution was extended to encompass the ashes used in its production. As stated by King Enrique IV in a royal decree enacted in 1456:

No one but the recipients of my royal privilege shall ever dare to produce ashes to make soap, with the exception of their employees, those having signed with them a lease contract, as well as those having obtained their consent ... (ADMSA. Legajo 56-2).

${ }^{3}$ A rab influence on the soap industry is illustrated by the adoption in ancient Spanish of the A rabic word for soap factory: A Imona. 
Between the $15^{\text {th }}$ and $17^{\text {th }}$ centuries, the Dukedom of Alcala deployed an active policy of acquiring olive trees and ash farms to ensure the supply of raw materials to the RAS and to deter smuggling (González Moreno, 1975). A search of the archives reveals, in fact, that the Dukedom of Alcalá filed extensive lawsuits against soap smugglers, in spite of the marginal significance of the illegal trade (ADMSA. Legajos 50-26, 50-47, 51-28; AMS. Section 1, Litigios, Folder 107, Number 3).

The RAS was located in an impressive building surrounded by warehouses (González Moreno, 1975). The soap production and distribution processes were run by some 50 employees and were characterized by tough working conditions. The heat of the soap production added to the usual high humidity and temperatures of Seville during five months of the year $\left(86-104^{\circ} \mathrm{F}\right.$ or $\left.30-40^{\circ} \mathrm{C}\right)$, posing considerable difficulties over working conditions and requiring the operators to work naked: "... only inside the reduced space of the office of weights and measures is it possible to breathe" (ADMSA. Legajo 50-19)

The royal decree that granted soap production and distribution privileges to the Dukedom of Alcalá (ADMSA. Legajos 55-17 and 57-7) stated that the local government should set the price of soap. Price changes in olive oil, ashes, or any other soap components caused frequent quarrels between interested parties about the fair price of soap (González Moreno, 1975). As we shall see, such conflicts also involved the Royal House and usually involved the development of an ensaye - a test that replicated the soap production process in order to track the standard cost of production.

Archival records refer to customary tradition at the time of addressing the governing rules of tests. However, our compilation of references to tradition in different primary documents, require us to concur with González Moreno (1975) that the governing rules for tests were relatively strict. The parties negotiated to select a team of soap experts outside of Seville to conduct the tests. Their independence and neutrality was further guaranteed by the parties' agreement to keep their contact with the experts to a minimum; in fact, the experts were not even allowed to overnight in the city during the testing period. A local judge supervised the tests and an accounting expert from the Catholic Church kept cost calculations and wrote the final report (ADMSA. Legajos 53-19). Tests were typically conducted on Saturdays, and the soap that was produced was stored in a sealed room until it solidified - usually on the following Monday. The final product was weighed and the cost of a pound of soap was thereby determined.

The date of the earliest test remains unclear. A 1675 document referred to the tests as "an operation that was being accomplished since the $15^{\text {th }}$ century by civil servants and the tenant of the soap factory, under royal authorization ..." (ADMSA. Legajo 55-13). In a similar vein, the records of a test conducted in 1525 stated that the performance of olive oil in that test was far superior to that of any preceding test (ADMSA. Legajo 514), suggesting that previous tests had already established a baseline. Our analysis of the extant archival evidence found no surviving records of tests until the period 1515-1520, and González Moreno (1975: 92) reports the development of a test in 1520. In summary, then, there are references in some primary documents to tests having been conducted during the $15^{\text {th }}$ century, but no concrete evidence of testing prior to 1520 . 
As stated in the royal decree that granted the monopoly to the Dukedom of Alcalá, the price of soap was ultimately the responsibility of the local government (ADMSA. Legajos 55-17, 57-7). However, the Royal House sometimes interfered in such decisions at the request of the Duke. At a meeting held on August 23, 1483, the Council of Seville allowed the RAS to raise the price of a pound of soap from 6 to 7 maravedies, because of reported cost increases in its basic components (ADMSA. Legajo 50-5). In 1492, when the price of olive oil dropped, the local government decreased the price of soap from 7 to 5 maravedies, but a royal decree revoked that decision (ADMSA. Legajo 50-13). On August 13, 1515, the royal house forwarded a decree to the local government to set the soap price at 6 maravedies.

\section{THE 1525 TEST}

In January, 1525, having observed that the price of soap was too high, the local government took the initiative to develop a test (ADMSA. Legajos 51-4, 53-27; AMS. Section 1, Litigios, Folder 116, Number 57). Over the years there was a running argument between the Duke of Alcalá and the local government as to whether the tests should be run using raw materials from the RAS inventories as the Duke argued or if they there should be new materials purchased specifically for the purpose of testing. In 1525, the wishes of local government officials prevailed, and new materials were purchased. (see ADMSA. Legajo 51-4).

Table 1:

The 1525 Test:

Cost of Raw Materials

\begin{tabular}{|c|c|c|c|}
\hline Materials & Consumption & Unit cost & Total cost \\
\hline Olive oil & 3 arrobas $^{4}$ & 140.5 maravedíes $^{5}$ & 421.5 maravedíes \\
\hline Ashes & 6 fanegas $^{6}$ & 50 maravedíes & 300 maravedíes \\
\hline Lime & $21 / 2$ fanegas & 39 maravedíes & 97,5 maravedíes \\
\hline Wood & 1 carga & 68 maravedíes & 61 maravedíes \\
\hline Lye & 6 cuartillos & 2,5 maravedíes & 15 maravedíes \\
\hline Total cost & & & 895 maravedíes \\
\hline
\end{tabular}

Sources: ADMSA. Legajos 51-4, 53-27. AMS. Section 1, Litigios, Folder 116, Number 57.

The olive oil was purchased at the Postigo del Aceite (Olive Oil Gate) of Seville. The reported price was the outcome of a weighted average of all olive oil acquisitions made during the preceding week: "those prices were used and distributed and each arroba cost 140.5 maravedies, once the five maravedies of alcabala (a sale tax) were taken into consideration" (ADMSA. Legajo 53-27). The cost of a fanega of ashes was 40 maravedies and 10 more maravedies were added for transportation and sundry costs. A carga (load) of wood cost 2 Reales, (68 maravedies). One tenth of the carga was not used in the test, however, so the final cost was decreased by 7 maravedies. Finally, the

\footnotetext{
41 quintal $=4$ arrobas $=100$ pounds $=128$ cuartillos.

51 ducado $=11$ R eales $=375$ maravedíes $=748$ blancas $=1,496$ nuevas.

61 fanega $=$ approximately 55.5 liters. 1 carga $=1$ carr etada $=8$ fanegas $=96$ al mu des.
} 
soap experts who ran the test decided on the consumption of lye and its concomitant cost.

The soap produced for the test weighed 7 arrobas and 11 pounds (186 pounds); thus one arroba of olive oil produced 62 pounds of soap, rather than the usual 50-51 pounds, and this was regarded as a "high performance of olive oil" (alto rendimiento del aceite). It was therefore concluded that "this test has been more successful than any of the preceding ones" (ADMSA. Legajo 51-4). Although materials used in the production of a pound of soap cost 4.818 maravedies, difficulties in handling decimals at the time required the experts to price it at " $41 / 2$ maravedies and one nueva", or 4.75 maravedies per pound (see Table 1).

As the Duke's representative, the manager of the RAS complained that soap production also involved other activities, and that their accompanying costs must be added to the cost of raw materials. The RAS manager's complaints are listed in the memorandum summarized in Table 2, which contains the expected annual cost of the support activities. By dividing the estimate of support costs by the expected annual production of soap, the parties obtained the cost of support activities per pound of soap, which the Duke believed should be incorporated into the final cost of each pound. Column 1 depicts the claims of the RAS management about items and prices to be considered for cost purposes; whereas Column 2 reports the final decision of local government representatives.

Table 2

The 1525 Test:

Estimation of Annual Costs

\begin{tabular}{|l|c|c|}
\hline \multicolumn{1}{|c|}{ Items } & $\begin{array}{c}\text { Proposal made by the } \\
\text { Administrator of the RAS }\end{array}$ & $\begin{array}{c}\text { Decision made by the } \\
\text { local government of } \\
\text { Seville }\end{array}$ \\
\hline $\begin{array}{l}\text { Repair and maintenance of cauldrons } \\
\text { Purchase of ropes and related items }\end{array}$ & 12,000 & 8,000 \\
\hline Preparation of cauldrons for the test & 6,000 & 4,000 \\
\hline Fabrication of sundry materials & 10,000 & 6,000 \\
\hline Taxes for ashes & 7,500 & 7,275 \\
\hline $\begin{array}{l}\text { Rent that would be obtained if the building } \\
\text { hosting the RAS were leased }\end{array}$ & 16,000 & 10,000 \\
\hline $\begin{array}{l}\text { Wages and food for the woman in charge of the } \\
\text { office of weights }\end{array}$ & 6,000 & 6,000 \\
\hline $\begin{array}{l}\text { Food and wages for the six operators of the shop } \\
\text { floor }\end{array}$ & 57,000 & 40,000 \\
\hline Yearly taxes for soap turnover & 120,000 & 40,000 \\
\hline $\begin{array}{l}\text { Returns on investment for materials and } \\
\text { machinery }\end{array}$ & 300,000 & 20,000 \\
\hline Salary of the administrator & 40,000 & 30,000 \\
\hline Total & & 171,275 \\
\hline
\end{tabular}

Sources: ADMSA. Legajos 51-4, 53-27. AMS. Section 1, Litigios, Folder 116, Number 57. 
Following is the rationale employed by RAS management and some of the counterarguments posed by local government:

i. If leased, the building that hosted the soap factory would have yielded an annual rent of 16,000 maravedies, and this opportunity cost should be considered in the overall cost.

ii. The wages of the six shop-floor operators should be considered. Representatives of the local government verified, however, that five out of the six shop-floor employees were slaves. Therefore, they agreed to budget their living costs, but removed their suggested wages of 17,000 maravedies/year.

iii. Investments made by the RAS in inventory and machinery would, in the opinion of the RAS management, have produced a $10 \%$ annual return, which would have amounted to 300,000 maravedies. As shown in Table 2, this figure was rejected by the local government, which incorporated 20,000 maravedies into the cost of soap.

Accepted claims amounted to 171,175 maravedies, which were allocated to the expected annual production of 417,000 pounds of soap. Non-production costs increased the cost per pound by 0.41 maravedies. The problems surrounding the handling of decimals, however, brought about the following consideration: “... it seems that each pound costs one nueva, which is one fourth of a maravedi as well as half a nueva, which is oneeighth of a maravedi ...". The resulting figure was rounded down to $0.25+0.125=$ 0.375 rather than 0.41 , which in absolute terms, meant a difference of 14,900 maravedies $(171,275$ - 156,275). The final report of the test stated: “... the remaining 14,900 maravedies are for the people [of Seville] because there is no way to allocate this amount to the pounds [of soap], and ultimately, this amount is consumed and are consumed [sic] by the people of Seville ...". Accordingly, the cost of a pound of soap was the result of the aggregation of raw material costs of 4.75 maravedies (Table 1) and support costs of 0.375 (Table 2).

The experts who carried out the test admitted, however, that the result demonstrated an outstanding performance of olive oil. Under normal conditions, one arroba of olive oil would have produced 50 to 51 pounds of soap, and if that result had occurred in this test, the cost of a pound of soap would have been 6 maravedies rather than the 4.75 maravedies calculated from the test of January, 1525. Consequently, they proposed to set the price of the soap at 6 maravedies and pointed out that "the test was beneficial for the people of Seville and worth being taken as a reference for the future" (ADMSA. Legajo 53-27).

\section{THE ANTECEDENTS OF THE 1615 TESTS}

In 1602, a test was performed in which the price of the soap was set at 18 maravedies (ADMSA. Legajo 53-17) ${ }^{7}$. However, the Duke of Alcala disagreed with this price and its supporting test and forwarded a memorandum of complaint to the King (ADMSA. Legajo 53-17). The Duke argued that the local government had not considered such

\footnotetext{
${ }^{7}$ This increase in soap cost may be explained by the high inflation rates that Seville experienced during the $16^{\text {th }}$ century.
} 
costs as the wages of salespeople that are instrumental to soap production and distribution and that they dismissed from the production cost the value of material wastage and theft. As a matter of principle, the Duke indicated that tests should be conducted with materials taken from the RAS inventories rather than newly purchased materials. The former, he stated, had a lower quality than the latter, to the extent that "stored materials are less and less strong as time goes by ... [and] one arroba of olive oil cannot produce 48 to 50 pounds of soap because of the bad quality of many [raw] materials, like lye." The Duke also reported that a pound of soap was being sold in the range of 20 to 32 maravedies in nearby cities, requiring him to face financial losses. The arguments of the Duke must have appealed to the King, for he ordered the development of a test that was conducted in 1603. On the basis of this test, the price of soap was set at 22 maravedies. The parties agreed that such a price "shall not change in the future, and thus no consideration will be made of increases or decreases in costs of raw materials." King Felipe III endorsed the agreement on September 3, 1603 (ADMSA. Legajo 53-19).

In 1614, however, changes in the cost of raw materials required a test that resulted in another new pricing for soap: 30 maravedies per pound (ADMSA. Legajo 53-27). The Judge of the Court of Seville, Mr. Juan del Castillo, stated that raw materials performed poorly in this test and endorsed the decision of the local government to set the price at 24 maravedies/pound. This decision prompted the Duke of Alcalá to forward a memorandum of complaints to the Royal Council. He claimed that many items had not been considered: the salaries of supervisors and foremen and the "interest of investments in materials, machinery and real estate" (ADMSA. Legajo 53-27). He asked the Royal Council to enforce the development of a new test, and, in the meantime, to set the price of soap at 33 maravedies/pound.

The Royal Council reacted on July 28, 1614 by ordering the development of a new test and enforcing a temporary price of 24 maravedies/pound for soap. Although the Duke recognized the willingness of the local government to conduct the test, he disagreed with the intention of the regulator of using "highly selected and strong materials." The Duke claimed that because the RAS made purchases "on a yearly basis, stored materials could not be as good or as strong as newly purchased materials" (ADMSA. Legajo 53-27).

The local government, in turn, claimed that the present price of soap was convenient for the Duke. It was argued that the Duke's correspondence with the Royal Council contained unsupportable claims that concealed his ultimate goal of delaying the development of a new test. Furthermore, the local government made an argument for not using RAS inventories in future tests:

...many [of the inventories] were dried and corrupted because they were purchased for [the Duke's] convenience. If the test were carried out with such materials, the soap price would be set at least at forty maravedies per pound. The present procedure was backed by tradition and did not cause any hardship for the Duke; thus, none of his claims was justified because the City was careful to ascertain prices of lye, olive oil, and other materials from verifiable sources. These prices were then incorporated into the cost of soap in the same manner as it has been done over the distant past ... (AMS. Section 4. Volume 1. Number 1) 
The local government supported its contention by attaching the results of a recent, undated test that determined a unit cost of 15.83 maravedies/pound. However, the price of the soap was set by the local government at 18 maravedies/pound "to deter further delays and lawsuits" from the Duke (AMS. Section 4. Volume 1. Number 1).

The Duke disagreed with the procedures that governed this test, however, and forwarded a new memorandum of complaints to the Royal Council. He claimed that the production and distribution processes for the soap involved more than fifty people and that the local government had considered the salaries of only twenty employees. The Duke also argued that "the RAS was housed in a huge building the maintenance of which required annual expenditures of at least 500 ducados and the yearly rent of which, if leased, would have produced 1,000 ducados... [Lastly, I have made] considerable investments in inventory and machinery" (ADMSA. Legajo 53-28). Such considerations, the Duke added in his letter, were dismissed by the local government, which only admitted one-quarter of the maintenance costs. In short, the Duke asked the Royal Council to enforce the inclusion of these costs into the price of the soap. He also claimed that tests should

...use inventories from the RAS [in the development of the test] and not pick up a number of singular and exclusive materials that are easy to use for a test but are not used in the normal running of the RAS. [The latter] required the supply of huge inventories to avoid materials shortages and equally implied that ashes and lime lessened their strength and died (sic) so that they produced half the soap that was obtained with materials that had been specifically purchased for the purpose (ADMSA. Legajo 53-28).

These arguments appealed to the Royal Council. On April 9, 1615, it forwarded an order to the local government to set the price of soap at 22 maravedies/pound and to conduct two tests: one to be run with RAS inventories and one to be conducted with newly purchased materials. These tests "should be conducted within the next forty days by [four] persons experienced in the art of soap production, two [people] appointed by each side. The results of the tests should be reported to the Royal Council, which shall make a fair decision."

This order must have worried the Duke of Alcalá, because he reiterated his point about the huge purchases made by the RAS to guarantee the regular supply of soap to the City of Seville, saying that "there was no justification for conducting a test with newly purchased materials." He also claimed that the soap price should be provisionally et at 30 maravedies rather than 22 maravedies per pound.

The local government also disagreed with the order of the Royal Council of April 9, 1615 , and reiterated its contention that a recent test determined the cost of soap to be 15.83 maravedies/pound. Drawing on the results of the aforementioned test, the local government refused to set the price at 22 maravedies, as ordered by the Royal Council (AMS. Section 4, Volume 1, Number 11). Instead, the local government asked for the authorization of the Royal Council to execute this price on a permanent basis, in view of the "maneuvers of the Duke to delay the test and thus to make profits from a convenient, current price of 24 maravedies/pound." Further, it was stated that the "Duke could manipulate the test by letting the RAS materials become corrupt and thus cause an 
insurmountable damage to the City and its inhabitants." The local government emphasized that all costs of raw materials and personnel had been taken into consideration and that the Duke attempted to include in the cost of soap production "the wages of some slaves who redeemed [in the tough working conditions of the RAS] their attempts to escape from their owners and for whom the Duke just provided food and lodging" (AMS. Section 4, Volume 1, Number 11).

On July 3, 1615, the Royal Council issued an order that maintained the conditions stated in the April 9 document, and appointed Mr. Juan del Castillo, a judge of the Court of Seville, as supervisor of the two tests. These conditions were slightly modified by an order of September 12, 1615, which appointed Mr. Pedro Maldonado, a fellow judge of the Court of Seville, as a co-supervisor of the tests. The judges, in turn, appointed Mr. Juan Bautista de Herrera, Contador (Accountant) of the Sacred Church of Seville to keep records of the tests and to prepare a final report (ADMSA. Legajo 53-28; AMS. Section 1, Litigios, Folder 116, Number 57).

\section{THE 1615 TESTS}

The Accountant first reported on the way in which the cost of materials was calculated:

... purchased materials are priced as shown in the attached receipts. Materials taken from the RAS are valued at their apparent purchase prices according to the certifications delivered by management ... (ADMSA. Legajo 53-28).

The prices of materials consumed for both tests are summarized in Table 3 .

Table 3

The 1615 Tests:

\section{Cost of Raw Materials.}

\begin{tabular}{|c|c|c|c|c|c|c|}
\hline \multirow[t]{2}{*}{$\begin{array}{c}\text { Raw } \\
\text { Materials }\end{array}$} & \multicolumn{3}{|c|}{ Test made with newly purchased materials } & \multicolumn{3}{|c|}{$\begin{array}{l}\text { Test made with materials taken from the } \\
\text { RAS inventories }\end{array}$} \\
\hline & Consumption & Unit Cost & Total Cost & Consumption & Unit Cost & Total Cost \\
\hline Lime & 2 fanegas & $\begin{array}{c}133.166 \\
\text { maravedies }\end{array}$ & $\begin{array}{c}266.33 \\
\text { maravedies }\end{array}$ & 2 fanegas & $\begin{array}{c}72.9166 \\
\text { maravedies }\end{array}$ & $\begin{array}{c}145.833 \\
\text { maravedies }\end{array}$ \\
\hline Ashes & 3.5 fanegas & $\begin{array}{c}255 \\
\text { maravedies }\end{array}$ & $\begin{array}{c}892.5 \\
\text { maravedies }\end{array}$ & 3.5 fanegas & $\begin{array}{c}187 \\
\text { maravedies }\end{array}$ & $\begin{array}{c}654.5 \\
\text { maravedies }\end{array}$ \\
\hline Wood & $\begin{array}{l}7 \text { arrobas and } \\
8 \text { pounds }\end{array}$ & $\begin{array}{c}98.25 \\
\text { maravedies }\end{array}$ & $\begin{array}{c}163.33 \\
\text { maravedies }\end{array}$ & $\begin{array}{c}3 \text { arrobas and } \\
2 \text { pounds }\end{array}$ & $\begin{array}{c}89.25 \\
\text { maravedies }\end{array}$ & $\begin{array}{c}68.7225 \\
\text { maravedies }\end{array}$ \\
\hline $\begin{array}{c}\text { Olive } \\
\text { Greaves }\end{array}$ & 0.5 fanegas & $\begin{array}{c}136 \\
\text { maravedies } \\
\text { perfanega }\end{array}$ & $\begin{array}{c}68 \\
\text { maravedies }\end{array}$ & 1.5 almud & $\begin{array}{c}136 \\
\text { maravedies } \\
\text { perfanega }\end{array}$ & $\begin{array}{c}17 \\
\text { maravedies }\end{array}$ \\
\hline Olive oil & 1 arroba & $\begin{array}{c}375.083333 \\
\text { maravedies }\end{array}$ & $\begin{array}{l}375.083333 \\
\text { maravedies }\end{array}$ & $\begin{array}{l}0.78125 \\
\text { arrobas }\end{array}$ & $\begin{array}{c}386.25 \\
\text { maravedies }\end{array}$ & $\begin{array}{c}301.75 \\
\text { maravedies } \\
\end{array}$ \\
\hline Lye & --- & --- & --- & $\begin{array}{l}0.140625 \\
\text { arrobas }\end{array}$ & $\begin{array}{c}40 \\
\text { maravedies }\end{array}$ & $\begin{array}{c}5.625 \\
\text { maravedies }\end{array}$ \\
\hline TOTAL & & & $\begin{array}{c}1,765.24 \\
\text { maravedies }\end{array}$ & & & $\begin{array}{c}1,193.43 \\
\text { maravedies }\end{array}$ \\
\hline
\end{tabular}

Source: ADMSA. Legajo 53-28. 
For the test undertaken with the newly purchased materials, the Accountant provided a number of clarifications. First, it was necessary to buy 12 fanegas of ashes, at 5 Reales/fanega, for a total cost of 2,040 maravedies. Transportation costs were 24 Reales (816 maravedies), and a 10\% tax was added to the resulting amount. The total cost of ashes, therefore, was 3,060 maravedies, and the unit cost was 255 maravedies/fanega, although only 3.5 fanegas of the 12 fanegas of ashes were actually consumed.

Second, the experts acquired 12 fanegas of lime, the total cost of which was 510 maravedies. With taxes, the final cost of lime was increased by 51 maravedies and was further increased by the rental cost of a horse to transport it (153 maravedies), bringing the total cost of lime to 1,598 maravedies and the unit cost to 133.166 maravedies. The actual consumption of lime was 2 of the 12 fanegas acquired.

Third, 8 quintales of wood were purchased for both tests, at a cost of 612 maravedies. Because the transportation cost of wood was 102 maravedies the total cost of wood was 714 maravedies and the unit cost was $89^{3 / 12}$ maravedies/quintal.

Consumption of wood for this test was written on the left-hand margin of the paper, and the following data were provided:

Wood delivered for the test Wood returned from the test Wood consumed in the test
12 arrobas and 10 pounds 5 arrobas and 2 pounds

7 arrobas and 8 pounds

Fourth, 2 fanegas of olive oil greaves ${ }^{8}$, with a unit price of 102 maravedies/fanega, were purchased for both tests, and transportation costs amounted to 68 maravedies. Thus the overall total for olive oil greaves was 272 maravedies and the unit cost to 136 maravedies/fanega. Again, the Accountant recorded the consumption of olive oil greaves for this test:

Olive greaves delivered for the test Olive greaves returned from the test Olive greaves consumed in the test

\section{2 almudes}

6 almudes

6 almudes

Sixth, the unit cost of olive oil was determined by calculating the weighted average of all purchases made between October 10 and November 10, as shown in receipts requested from the supervisor of the Olive Oil Gate. Twelve different prices were provided, totaling 3,979.5 maravedies, which, after adding the appropriate taxes, yielded a unit cost of $375^{1 / 12}$ maravedies/arroba (ADMSA. Legajo 53-28).

In a similar vein, the test that used materials from the RAS inventory required a number of clarifications by the Accountant. First, the cost of ashes was determined upon the certification provided by the RAS Accountant. The cost was 5 Reales/fanega plus a $10 \%$ alcabala (sales tax), for a total unit cost of 187 maravedies. 
Second, information about the cost of lime was gathered from the accounting books of the RAS, which revealed the purchase of 18 carretadas for $251 / 2$ ducados. With the addition of taxes, the total cost became 28 ducados (10,500 maravedies), which in turn brought the unit cost of lime to $72^{11 / 12}$ maravedies/fanega.

Third, wood had the same price for both tests, as noted above. Wood consumption for this test was recorded as follows:

Wood delivered for the test
Wood returned from the test
Wood consumed in the test
8 arrobas and 17 pounds

5 arrobas and 15 pounds

3 arrobas and 2 pounds

Fourth, oil greaves were also purchased for both tests and the consumption was recorded as follows:

Olive greaves delivered for the test

Olive greaves returned from the test

Olive greaves consumed in the test
12 almudes

10 almudes and 2 fourths

1 almud and 2 fourths

Fifth, receipts issued by the supervisor of the Olive Oil Gate were used to determine the cost of olive oil. These receipts covered the period from September 10 to October 10, 1615. A calculation of the weighted average price of olive oil yielded a unit cost of $335^{3 / 12}$ maravedies, for a total cost of 386.25 maravedies/arroba, including taxes.

Drawing on these data, the cost of a pound of olive oil specifically purchased for the test was calculated to include the cost of transportation (32.66 maravedies per pound of olive oil) and to exclude the cost of transportation (24.4166 maravedies/pound). The test using materials from the RAS inventory, on the other hand, produced a unit cost of 27.66 maravedies/pound (ADMSA. Legajo 53-28). Although this calculation did not encompass any of the administration costs that constituted a permanent matter of concern for RAS, the parties agreed that administration costs amounted to 10 million maravedies per year, yielding a total cost of 37.66 maravedies per pound for the finished soap. In short, the test run with materials taken from the RAS inventories produced a total cost for soap that was 5 maravedies higher than the test run with materials purchased specifically for the purpose. Regrettably, our search of the archives did not reveal the final decision - the price at which soap was set after the 1615 tests.

\section{THE 1640-1692 PERIOD}

In 1640, Mr. Antonio de la Cerda, Duke of Medinaceli, married the heiress of the Dukedom of Alcalá and assumed the royal privilege of making and distributing soap to the City of Seville and its area of influence. On January 18, 1643, the parties agreed to set the price of soap at 30 maravedies for the next four years and at 32 maravedies for the four subsequent years. King Felipe IV endorsed this agreement on November 2, 1643 (ADMSA. Legajo 53-38; AMS. Section 4, Volume 4, Number 15), subject to several conditions. 1) These prices were not to be contingent upon the price of olive oil.

8 Olive oil greaves - byproducts in the production of olive oil - were used, for their corrosive properties, in the production of soap. 
2) The soap market was regulated by royal privilege, and the price of soap would therefore be revised if changes occurred in the terms of the privilege. 3) Quality conditions for soap (i.e., color, tightness) and olive oil performance (i.e., 52 pounds per arroba of olive oil) were established. 4) A supply of soap would be provided to 14 shops, which must be opened 24 hours a day. The location of the shops was also negotiated, and it included the various neighborhoods of Seville and its area of influence. 5) Trade at the shops must be restricted to bread, olive oil, soap, and coal. Weighing devices would have to be cleaned and sealed, and the seal was to be checked by a City supervisor every four months. 6) The price of the soap would have to be permanently displayed.

In spite of this agreement, conflicts between the local government and the Duke of Medinaceli occurred during the second half of the $17^{\text {th }}$ century, centering on bitter arguments about the procedures that governed the tests and determined the cost of soap. As the Duke of Medinaceli wrote in an internal memorandum to the management of the RAS about issues to be considered during the development of the tests:

First, we have to determine the cost of the materials in each of the tests ${ }^{9}$. We should calculate and add all the corresponding taxes as well as all costs legitimated by extant documents.

Second, we have to discover the sources of differences between the two tests - that is, whether they correspond to taxes or any other item - and all calculations should be made very clearly and separately.

Third, we have to continually update our accounting books and check if there is anything left.

Fourth, the whole process has to be monitored to the letter (a la letra, in detail). Otherwise, it is impossible to discern the price of the items and the level of consumption (ADMSA. Legajo 55-4).

On December 6, 1672 the King answered the Duke's complaints about some items in the cost of soap production being ignored, and ordered a test that "should comprise all costs and rights so that the price reflects them all" (ADMSA. Legajo 55-13). The local government, however, did not obey this order on the grounds that it had the right to set the price of soap and to establish the governing procedure of the tests.

On May 19, 1692, the local government held a plenary session to set the price of soap at 28 maravedies. The Duke of Medinaceli disagreed with this decision and forwarded a memorandum of complaint to the King (ADMSA. Legajo 55-4; AMS. Section 4, Volume 1, Number 16). His flamboyant memorandum depicted errors in the development of the supporting test and provided several examples of the many administration costs not included in the production cost. Of interest for this paper is the Duke's complaint about the omission of the priest's salary:

[To guarantee the supply of soap to the City of Seville, the RAS] is obliged to operate on Sundays. This forces me to provide a Sunday mass service for foremen and operators, because they are naked while running production and cannot leave the premises in such a condition (ADMSA. Legajo 55-4).

\footnotetext{
${ }^{9} \mathrm{He}$ refers to tests like those conducted in 1615 , in which the cost of soap production is calculated after comp aring performance of newly purchase materials versus those taken from the RAS inventories.
} 
The Duke also claimed that the local government dismissed his demands to set "my earnings as a constitutive part of price.” In particular, he argued:

[The local government] does not admit any earning to me as a purveyor, as it has done in the past, and as it is currently done in the cities of Cádiz and Xerez. Furthermore, it has recognized an additional 8 per cent to prevent the deterioration of the materials and the stored soap. The contention that spreads throughout the City is that if such expense is considered, then there will be no allowance for earnings. This lacks support [because] what is expense is not earnings, and earnings cannot be denied to the purveyor. Moreover, the privilege will be useless if I cannot profit from it" (ADMSA. Legajo 55-4).

\section{GENERAL DISCUSSION}

Historical research has enhanced our knowledge of the role of cost accounting in firms that are operating in competitive markets. For example, those under the Neoclassical Economics School have found that increasing competition slashed the profit margins of firms around the time of the British Industrial Revolution and in $19^{\text {th }}$ century USA, motivating the deployment of cost accounting calculations as companies sought opportunities for cost improvements (Johnson and Kaplan, 1987). Yet we still have much to learn about the role of cost accounting in the regulated markets that dominated many Southern European economies near the end of the Middle Ages and the during Renaissance and the extent to which it was instrumental in the deployment of public policy by authorities. In the City of Seville, for example, bricks (AMS. Section 3, Volume 13, Number 15), fish (AMS. Section 4, Volume 29, Number 16), and olive oil (AMS. Section 4, Volume 4, Number 15$)^{10}$ were three items in the long list of goods that operated under stiff market regulations. In this study, we examined the case of the soap production and distribution monopoly in the City of Seville - a monopoly granted by the King of Castille to the Duke of Alcalá in 1423, while placing the right and responsibility of the pricing decision in the hands of the local government. Over the centuries, the Duke of Alcalá and the local government deployed tests that reproduced the soap production process and designed a complex system of cost calculations to track the real cost of soap as a basis for price negotiations.

\section{Discussion from the perspective of institutional sociology}

For the soap tests to be considered an institution required the regular development of that practice as well as the conferral of external support to the testers (Scott and Meyer, 1983: 149). It appears that the parties developed tests at least as early as 1520 (González Moreno, 1975: 92), and again in 1525 (ADMSA. Legajo 51-4; AMS. Section 1, Litigios, Folder 116, Number 57), 1602 (ADMSA. Legajo 53-17), 1603 (ADMSA. Legajo 5319), 1614a (ADMSA. Legajo 53-27), 1614b (AMS. Section 4, Volume 1, Number 11), 1615 (ADMSA. Legajo 53-28; AMS. Section 1, Litigios, Folder 116, Number 57), 1643 (ADMSA. Legajo 53-38; AMS. Section 4, Volume 4, Number 15), 1672 (ADMSA. Legajo 55-13), 1675 (ADMSA. Legajo 55-13), and 1692 (ADMSA. Legajo 55-4, AMS. Section 4, Volume 1, Number 16). We were able to find records of two tests dating back to 1520 and 1525, no evidence for the period 1525-1602, and support for the development of nine tests during the $17^{\text {th }}$ century.

\footnotetext{
${ }^{10}$ Regrettably, available archival documents on these regulated items are sparse and not well preserved.
} 
Other primary sources suggest that the development of tests constituted a regular activity of the parties. For example, the report that certified the 1675 test stated in its preamble: "... testing of the product of the almonas, or soap factories, is an operation that has been accomplished from the $15^{\text {th }}$ century ..." (ADMSA. Legajo 55-13). In a similar vein, in its report to the Royal Council of 1614, the local government referred to the procedures that ruled the tests as practices "backed by tradition" (AMS. Section 4. Volume 1. Number 1), and the tests were regarded as operations that "have been done in the distant past" (Ibidem). It is important to note that although surviving records reveal only four tests prior to 1614 (1520, 1525, 1602, and 1603), references to "tradition" and the "distant past" were made in 1614 - an indication that there may be missing records in the archives that would have shown us enough tests occurring in the distant past to constitute tradition.

In sum, the development of soap tests were governed by customary, non-written traditions during a period that lasted at least from 1520 to 1692 and, arguably, on a regular basis. We contend that these data provide support for the requirement of "usual" practice that institutional sociologists attribute to the notion of "institution" (Scott and Meyer, 1983: 149; Scott, 2001)."

Institutions are distinguished by investing the parties with support before external constituents (Scott, 2001). According to one document, the Royal Council enacted a decree on April 9, 1615 that obliged the local government to set the price of soap at 30 maravedies. Nevertheless, the local government denied the implementation of the royal decree because a recent test had determined the cost of soap to be 15.83 maravedies/pound (AMS. Section 4, Volume 1, Number 11), a decision that should be examined in the context of a political regime that differs from present-day democracies. As noted above, Spain was ruled during our observation period by the absolutist monarchy of the Habsburgs (Kamen, 1997). It is difficult to imagine that a local government would disobey the order of an absolute monarch unless its decision was supported by a higher authority. Perhaps test results could not be openly challenged by any external party - even by an absolute king. Thus the development of tests and their accompanying cost calculations may have invested the parties with support before powerful constituents like the absolute monarchy, suggesting that the tests complied with the requirement of social endorsement that characterizes institutions (Scott, 2001).

The credibility of the tests was reinforced by their technical appearance and by their association with external experts (Richardson, 1987; Covaleski and Dirsmith, 1988: 6) who were independent from the parties (e.g., soap masters brought from other cities), supervised by local judges, and certified by an accountant of the Catholic Church. Importantly, data incorporated into cost calculations were certified either by suppliers of raw materials or by the accounting records of the RAS. The parties drew on this technical imagery of accounting calculations in support of their claims. The Duke, for example, relied on a technical discourse to channel his complaints against specific elements of the tests. He demanded that they be conducted with materials from the RAS inventory in order to reproduce standard conditions of soap production and he insisted that such items as the priest's salary (ADMSA. Legajo 55-4; AMS. Section 4, Volume 1, 
Number 16) and the opportunity costs for lost rent to the RAS (ADMSA. Legajo 51-4) be included in the total cost of a pound of soap.

Institutional sociologists predict that individuals and organizations will attempt to create an environment in which they can enact their claims behind a façade of technical arguments (see, e.g., Dacin et al., 2002). The Duke supported this position when he enacted the practice of permanent lobbying before the King in order to create new legitimating beliefs (Suchman, 1995). Interesting for our purposes is the fact that the latitude exhibited by the Duke to manipulate the terms of the tests was contingent upon his political influence in the Royal House (Oliver, 1991). Thus the King's support for he inclusion of "... all costs and rights" (ADMSA. Legajo 55-4, emphasis added) in the cost of soap had to wait until 1672, when the powerful Dukedom of Medinaceli assumed the management of RAS. The political influence of the Dukedom of Medinaceli at that time may be signaled by the Duke's appointment on February 22, 1680 as Prime Minister of Spain. Paraphrasing Burchell et al. (1980: 17), we contend that cost accounting became one of the mechanisms around which private versus public interests were negotiated. The apparent acceptance of the tests by the parties in the public domain was accompanied by active agency to shape the tests at the convenience of the Duke.

Finally, in accordance with predictions of institutional sociologists (Meyer and Rowan, 1977), the legitimizing effects of the tests outweighed their intended, economic purposes of price setting (Carruthers, 1995). In practice, cost calculations became a rhetorical element in arriving at a price for soap. As we have seen, the price-setting decision did not necessarily draw upon the outcome of the tests. In the 1525 test, for example, the production cost was 5.125 maravedies, but the price was set at 6 maravedies because of the strong performance of olive oil in the test (ADMSA. Legajo 51-4). In 1614, the production cost that resulted from the test was 30 maravedies, but the price was set at 24 maravedies because of the "poor quality" of the materials (ADMSA. Legajo 53-19). In the second test conducted in 1614, on the other hand, the cost of producing the soap was 15.83 maravedies, but the price was set at 18 maravedies "to deter further delays and lawsuits [from the Duke]" (ADMSA. Legajo 53-19). In short, in spite of the appearance of conformity that the parties exhibited towards the tests and their reliance on technical judgments, the final price was largely the outcome of non-technical considerations.

\section{Discussion from the perspective of historical research in management accounting}

The development of soap tests in 16th and 17th century Seville provides some insights into the evolution of the management of public affairs during this observation period. As noted above, the doctrine of the Schoolmen inspired the deployment of regulated markets in Spain and its overseas colonies. As intended, regulated markets ensured a "just price", which would ultimately protect the poor (De Roover, 1967). In the case of the 1525 soap monopoly, the notion of a "just price" was operationalized into what present-day terminology would label a "rate-of-return regulation" (Laffont and Tirole, 1993). The price of a public good equalled its average cost, which implied that the soap monopolist seemingly adopted the role of a public servant with marginal or no financial goals and with an interest in providing service to the people of Seville. This situation is illustrated by the handling of decimals in the test of 1525; figures were rounded down to benefit the people of Seville irrespective of financial implications for the Duke (ADMSA. Legajo 53-27). 
In contrast, the end of our observation period in 1692 depicts a different situation. Drawing on the logic of cost accounting calculations, the Duke claimed his right to profit from the monopoly: "... what is expense is not earnings, and earnings cannot be denied to the purveyor. Moreover, the privilege will be useless if I cannot profit from it" (ADMSA. Legajo 55-4). In other words, the Duke demanded what in present-day terminology would be called "rate-of-return regulation" with a limited allowance for profits or a "price cap" - a soap price that allowed for private profits with future updates, irrespective of increases in the cost of resources in the production of soap (Laffont and Tirole, 1993). Such rationale for price updates was used in 1603 (ADMSA. Legajo 53-19), and especially in 1643, when price increases were set for the next three years irrespective of changes in the cost of raw materials or other resources (ADMSA. Legajo 53-38. AMS. Section 4, Volume 4, Number 15). Although the Duke did not bother to record his financial goals in writing, he was obviously aware of some social resistance to profit-making from the supply of a public good: "... the contention that spreads the City is that if such expense is considered, there will be no allowance for earnings" (ADMSA. Legajo 55-4).

Archival evidence from the $15^{\text {th }}$ to $17^{\text {th }}$ century allowed us to address the development of soap production testing from the perspectives of the two parties involved - the Dukedom of Alcalá and the local government of Seville - and to interpret their correspondence with the King. This research allows us to report on several findings about cost accounting in an early regulated market. 1) There is written documentation available about Rennaisance cost accounting systems, featuring targets, predictions, and results. 2) Using the languae of Ezzamel and Hoskins (2002, accounting was used in this early period as a creator of value. 3) The extensive data collected for the soap production testing did not appear to strongly influence decision making. 4) Although a wide variety of sophisticated cost accounting techniques were employed during this peirod, they appear not to have been incorporated into the disciplinary nexus of managemen practices or to be utilized in the meausrement of human performance. The following section summarizes of each of these findings.

First, our evidence provides support for the contention that early cost management systems attempted to turn performance into writing and, by doing so, initiated practices in which targets and results were extrapolated into the future (Hoskin and Macve, 1994; Ezzamel, 1994, 1997). The use of writing is exemplified by the careful account of tests kept by the Accountant of the Catholic Church. In a similar vein, extrapolation of results into the future is illustrated by the concluding reminder of the 1515 test, which stated that performance "was beneficial for the people of Seville and worth being taken as a reference for the future" (ADMSA. Legajo 51-4; AMS. Section 1, Litigios, Folder 116, Number 57; emphasis added). Further, the Agreement of 1643 between the RAS and the local government, drew upon an established standard (ADMSA. Legajo 53-38; AMS. Section 4, Volume 4, Number 15) that was incorporated into the control procedures of the RAS to assume a performance of 52 pounds of soap per arroba of olive oil.

Second, the parties deployed a complex system of cost calculations that attached values to objects or, as Ezzamel and Hoskin (2002) would say, accounting was used as a creator of value. Cost calculations were implemented by the RAS - a small-sized firm providing support for Boyns and Edwards' (1997:22) contention that "there is no reason why, a priori, one should expect a link between the development of large-scale business 
and that of management accounting." Admittedly, some cost allocations were relatively straightforward. For example, the cost of raw materials was calculated through the aggregation of purchase and transportation costs plus corresponding taxes. Conversely, other calculations involved a deep understanding of production costing. For example, administration and non-production costs were allocated to soap costs as a function of the annual production schedule of the RAS, which in turn required a precise forecasting of soap demand. Furthermore, the RAS argued that present investments in inventories and machinery could have been earning a $10 \%$ interest rate and requested that this factor be incorporated into the production cost (ADMSA. Legajo 51-4). Similarly, the RAS asserted that alternative leasing of the buildings that housed the factory would provide the Duke with rents that should be included in the cost of the product. The parties also determined the standard performance of olive oil, which became a crucial element in the proper calculation of the cost of soap. In short, such calculations anticipated the utilization of standards based on expectations from prior results some centuries before the advent of scientific management (Fleischman and Tyson, 1998: 93).

Taken together, these first two findings reveal the development of forms of cost-keeping practices that were not double-entry based (Miller and Napier, 1993). They also signaled the expertise of the RAS in ascertaining the constitutive elements of product costing and, ultimately, the notion of a firm's profit. Such understanding was eloquently framed as a purely technical discourse that attempted to persuade the King and the local government about the elements that should be incorporated into the costs of soap production (Carruthers, 1995). We observed stability in the cost categories, however, as well as in the soap production technology used during our period of study.

Third, a debatable issue in historical management accounting research is the extent to which such data informed managerial decision-making (i.e., Hoskin and Macve, 2000). Regrettably, there is no available $16^{\text {th }}$ and $17^{\text {th }}$ century evidence for proper comparison purposes. Our findings suggest that the RAS did not use cost data from the tests for regular managerial decision making, with the exception of the overall understanding outlined in the 1643 agreement that an arroba of olive oil should produce 52 pounds of soap (ADMSA. Legajo 53-38; AMS. Section 4, Volume 4, Number 15) and in the 1525 test (ADMSA. Legajo 51-4; AMS. Section 1, Litigios, Folder 116, Number 57). As noted above, this situation may have been caused by the system of rate-of-return/price cap regulation that characterized price setting by the local government of Seville. On the one hand, such results are similar to those found by Boyns and Edwards (1997a, 1997b), who reported little development of costing information in management decision making in $19^{\text {th }}$ century UK. On the other hand, such results depart from those reported by Carmona et al. (1997, 2002), who found that cost data were used in managerial decision making in the Royal Tobacco Factory of Seville in the $18^{\text {th }}$ century. Thus, our findings also deviate from those of Tyson (1998), who reported the use of cost data in business decision making in US textile mills of the early $19^{\text {th }}$ century.

Finally, our findings show no indication of accounting having been incorporated into the disciplinary nexus of management practices (Ezzamel, Hoskin and Macve, 1990), and thus no shift has been found to extend standards of raw materials to measure human performance (Hoskin and Macve, 2000). We contend that the absence of cost data on human performance might be attributed to the extensive use of slaves in shop floor operations (ADMSA. Legajo 51-4). We have also detected the use of a wide variety of 
complex cost accounting techniques during our observation period - a period that has been widely neglected by management accounting historians. These techniques involved issues that, expressed in present-day terminology, comprised standards of raw material consumption (e.g., olive oil), production capacity (i.e., annual estimation of the RAS turnover), calculation of wastage (i.e., raw materials in the tests), and opportunity costs (i.e., factory building and investment in inventory and machinery). It is remarkable that such sophisticated techniques were employed at a time when it was not possible to handle decimals.

\section{Extensions}

In this study, we have examined the systems of cost calculations governing the development of soap tests in the regulated market that characterized the economy of the City of Seville between the $15^{\text {th }}$ and $17^{\text {th }}$ centuries. Other goods such as bricks, olive oil and fish were subjected to stiff regulations in the City of Seville, however, at least during a large portion of this period. Surviving records for these goods are not well preserved, which poses research problems. Yet there were other places where regulated markets operated as a dominant economic form: in Southern Europe, for instance, and in Latin America during the Renaissance. Investigations on the role of cost calculations in price setting would enhance an understanding of the extent to which cost accounting practices mediated the undertakings of public sector agencies and the interface between the state and private sectors (i.e., Hoskin and Macve, 2000; Carmona and Macías, 2001), as well as the relationship between the state and such powerful constituents as the knighthood and the Catholic Church. In a similar vein, we consider a promising research area to be the historical examination of the state's efforts to stress the imagery of objectivity of cost data in order to garner public endorsement - to trace the history of accounting as a form of rhetoric in public sector contexts. Finally, investigation of cost accounting practices in the price setting decision in present-day, deregulated markets (i.e., US energy) and privatized sectors (i.e., the UK water supply in 1989) may also highlight the connections between the technical and the discursive natures of management accounting systems. 


\section{REFERENCES}

\section{Archivo del Ducado de Medinaceli. Sección de Alcalá (ADMSA)}

ADMSA. Legajo 50-5.

ADMSA. Legajo 50-13.

ADMSA. Legajo 50-19.

ADMSA. Legajo 50-26.

ADMSA. Legajo 50-47.

ADMSA. Legajo 51-4.

ADMSA. Legajo 51-28.

ADMSA. Legajo 53-17.

ADMSA. Legajo 53-19.

ADMSA. Legajo 53-2.

ADMSA. Legajo 53-27.

ADMSA. Legajo 53-28.

ADMSA. Legajo 53-38.

ADMSA. Legajo 55-4.

ADMSA. Legajo 55-13.

ADMSA. Legajo 55-16.

ADMSA. Legajo 55-17.

ADMSA. Legajo 56-2.

ADMSA. Legajo 57-7.

\section{Archivo General de Indias (AGI)}

AGI. Sección Patronato. Legajo 25. Ramo 1.

\section{Archivo Municipal de Sevilla (AMS)}

AMS. Section 1, Litigios, Folder 107, Number 3.

AMS. Section 1, Litigios, Folder 116, Number 57.

AMS. Section 3,Volume 13, Number 15.

AMS. Section 4, Volume 1, Number 11.

AMS. Section 4, Volume 1, Number 16.

AMS. Section 4, Volume 4, Number 15.

AMS. Section 4, Volume 29, Number 16.

Boyns, T. \& Edwards, J.R. 1997a. Cost and Management Accounting in Early Victorian Britain: A Chandleresque Analysis? Management Accounting Research 8 (1). 19-46.

Boyns, T. \& Edwards, J.R. 1997b. The Construction of Cost Accounting Systems in Britain to 1900: The Case of the Coal, Iron and Steel Industries. Business History 39 (3). 1-29.

Caballero Bonald, J.M. 1991. Sevilla en tiempos de Cervantes. Planeta. Barcelona.

Carmona, S. \& Donoso, R. 1999. Precios, espíritu de beneficios y sistemas de costes, Revistas Española de Financiación y Contabilidad. Number 100. 403-424. 
Carmona, S., Ezzamel, M. \& Gutiérez, F. 2002. The Relationship between Accounting and Spatial Practices in the Factory. Accounting, Organizations and Society 27 (3). 239-274.

Carmona, S., Ezzamel, M. \& Gutiérrez F. 1997. Control and Cost Accounting Practices in the Spanish Royal Tobacco Factory. Accounting, Organizations and Society 22 (5). 411446.

Carmona, S. \& Macías, M., 2001. Institutional Pressures, Monopolistic Conditions, and the Implementation of Early Cost Systems: The Case of the Royal Tobacco Factory of Seville (1820-1887). Abacus 37 (2). 139-165.

Carruthers, B. 1995. Accounting, Ambiguity, and the New Institutionalism. Accounting, Organizations and Society 20 (4). 313-328.

Covaleski, M. \& Dirsmith, M.W. 1995. The Preservation and Use of Public Resources: Transforming the Immoral into the Merely Factual. Accounting, Organizations and Society $20(2 / 3) .147-173$.

Covaleski, M.A. \& Dirsmith, M.W., 1988. The Use of Budgetary Symbols in the Political Arena: An Historically Informed Field Study. Accounting, Organizations and Society 13 (1). 1-24.

Covaleski, M.A.; Dirsmith, M.W. \& Samuel, S. 1996. Managerial Accounting Research: The Contribution of Organizational and Sociological Theories. Journal of Management Accounting Research 8. 1-35.

Dacin, T.M.; Goodstein, D. \& Scott, W.R. 2002. The Rebirth of Institutional Theory. Academy of Management Journal. 40 (3). 115-145.

De Roover, R. 1967. The Scholastics, Usury, and Foreign Trade. Business History Review XLI (3). 257-271.

Deephouse, D.L. 1996. Does Isomorphism Legitimate? Academy of Management Journal 39 (4). 1024-1036.

DiMaggio, P.J. 1988. Interest and Agency in Institutional Theory. In: Zucker, L.G. (ed). Institutional Patterns and Organizations: Culture and Environment. Ballinger. Cambridge, MA. 3-21.

Dirsmith, M.W. 1986. Social Environments and Organizational Accounting: A Discussion. Accounting, Organizations and Society 11 (4/5). 357-367.

Domínguez Ortíz, A. 1984. Historia de Sevilla: La Sevilla del Siglo XVII. Servicio de Publicaciones de la Universidad de Sevilla. Sevilla.

Donoso Anes, R. 1996. Una contribución a la historia de la contabilidad: Análisis de las prácticas contables desarrolladas por la tesorería de la Casa de la Contratación de las Indias de Sevilla: 1503-1717. Servicio de Publicaciones de la Universidad de Sevilla. Sevilla.

Ezzamel, M. 1994. From Problem Solving to Problematization. Relevance Revisited.

Critical Perspectives on Accounting 5 (3). 269-280. 
Ezzamel, M. 1997. Accounting, Control and Accountability: Preliminary Evidence from Ancient Egypt. Critical Perspectives on Accounting 8 (6). 563-601.

Ezzamel, M. \& Hoskin, K. 2002. Retheorising the Relationship between Accounting, Writing and Money with Evidence from Mesopotamia and Ancient Egypt. Critical Perspectives on Accounting. 13 (3). 333-367.

Ezzamel, M., Hoskin, K.W. \& Macve, R.H. 1990. Managing It all By Numbers: A Review of Johnson \& Kaplan's Relevance Lost. Accounting and Business Research 20 (78). 153166.

Fleischman, R.K. \& Tyson, T.N. 1998. The Evolution of Standard Costing in the U.K. and U.S.: From Decision Making to Control. Abacus 34 (1). 92-119.

González Moreno, J. 1975. Las Reales Almonas de Sevilla: 1397-1855. Instituto de la Grasa y sus Derivados Sevilla.

Hamilton, E.J. 1975. El Tesoro Americano y la Revolución de los Precios en España. Barcelona. Ariel

Hernández Borreguero, J.J. 2003. El Cabildo Catedral de Sevilla: Organización y Sistema Contable. Unpublished Ph.D. Dissertation. University of Seville.

Hoskin, K.W. \& Macve, R.H. 1986. Accounting and the Examination: A Genealogy of Disciplinary Power. Accounting, Organizations and Society 11 (2). 105-136.

Hoskin, K.W. \& Macve, R.H. 1988. Genesis of Accountability: The West Point Connection. Accounting, Organizations and Society 13 (1). 37-73.

Hoskin, K.W. \& Macve, R.H. 1994. Writing, Examining, Disciplining: The Genesis of Accounting's Modern Power. In Hopwood, A. and Miller, P. (Eds.), Accounting as Social and Institutional Practice. Cambridge, UK. Cambridge University Press. pp. 67-97.

Hoskin, K.W. \& Macve, R.H. 2000. Knowing More as Knowing Less? Alternative Histories of Cost and Management Accounting in the USA and the UK. The Accounting Historians Journal 27 (1). 91-149.

Johnson, H.T. \& Kaplan, R.S. 1987. Relevance Lost. Rise and Fall of Management Accounting. Boston. Harvard Business School Press.

Kamen, H. 1997. Felipe II de España. Madrid. Siglo XXI Editores.

Laffont, J.-J. \& Tirole, J. 1993. A Theory of Incentives in Procurement and Regulation. Cambridge, MA. The MIT Press.

Lynch, J. 1997. La España de Felipe II. Barcelona. Grijalbo-Mondadori.

Meyer, J.W. 1986. Social Environments and Organizational Accounting. Accounting, Organizations and Society 11 (4/5). 345-356.

Meyer, J.W. \& Rowan, B. 1977. Institutionalized Organizations: Formal Structure as Myth and Ceremony. American Journal of Sociology 83 (2). 340-363. 
Miller, P. 1990. On the Interrelationship Between Accounting and the State. Accounting, Organizations and Society 15 (4). 315-338.

Miller, P. \& Napier, C. 1993. Genealogies of Calculation. Accounting, Organizations and Society 18 (7/8). 631-647.

Morales Padrón, F. 1977. Historia de Sevilla: La Ciudad del Quinientos. Servicio de Publicaciones de la Universidad de Sevilla. Sevilla.

Oliver, C. 1991. Strategic Responses to Institutional Processes. Academy of Management Review 16 (1). 145-179.

Piernas Hurtado, J. 1907. La Casa de Contratación de las Indias. Madrid. El Ateneo.

Richardson, A. 1987. Accounting as a Legitimating Institution. Accounting, Organizations and Society 12 (4). 341-355.

Scott, W.R. 2001. Institutions and Organizations. Beverly Hills, CA. Sage Publications $\left(^{\text {nd }}\right.$ edition).

Scott, W.R. 1995. Institutions and Organizations. Beverly Hills, CA. Sage Publications (First edition).

Scott, W.R. 1987. The Adolescence of Institutional Theory. Administrative Science Quarterly 32 (2). 493-511.

Scott, W.R. \& Meyer, J.W. 1983. The Organization of Societal Sectors. In Meyer, J.W. and Scott, W.R. (eds.). Organizational Environments: Ritual and Rationality. Sage Publications. Beverly Hills, CA. 129-153.

Scott, W.R. \& Meyer, J.W. 1991. The Organization of Societal Sectors: Propositions and Early Evidence. In Powell, W.W. and DiMaggio, P.J. (eds.). The New Institutionalism in Organizational Analysis. University of Chicago Press. Chicago. 124-149.

St. Thomas Aquinas, 1273. Summa Theologiae. Montreal. The Institute of Medieval Studies (5 Volumes, 1941-1945).

Suchman, M.C. 1995. Managing Legitimacy: Strategic and Institutional Approaches. Academy of Management Review 20 (3). 571-610.

Tyson, T.N. 1998. Mercantilism, Management Accounting or Managerialism? Cost Accounting in Early Nineteenth-Century US Textile Mills. Accounting, Business and Financial History 8 (2). 211-229.

Vázquez de Prada, V. 1990. Felipe II. Barcelona. Editorial Juventud. 
NOTAS 